\title{
Faktor Cashback Dalam Penggunaan Fitur Pembayaran Go-Pay Melalui Aplikasi Go-Jek Di Burger King Central Park
}

\author{
Johannes Kurniawan ${ }^{1}$ \\ Akademi Pariwisata Bunda Mulia ${ }^{1}$ \\ email: jkurniawan@bundamulia.ac.id
}

\begin{abstract}
Abstrak
Dalam merealisasikan promosi tersebut Burger King bekerja sama dengan Go-Jek untuk memberlakukan promosi cash back dengan menggunakan fitur pembayaran Go-Pay dengan menggunakan aplikasi Go-Jek. Alasan dilakukan nya penelitian ini adalah karena banyaknya perubahan promosi yang bervariatif dengan berbagai cara dengan periode yang berbeda-beda juga. Tujuan dari penelitian ini yaitu, untuk mengetahui pengaruh cash back menggunakan fitur pembayaran Go-Pay menggunakan aplikasi Go-Jek.Penelitian ini adalah penelitian asosiatif kausal dengan menggunakan pendekatan kuantitatif kausal. Teknik pengumpulan data yang dilakukan adalah dengan menyebarkan kuesioner,dan hasil dari data kuesioner tersebut akan dianalisis. Berdasarkan distribusi nilai F didapatkan F hitung sebesar 69,881>F table sebesar 3.95 dengan tingkat signifikans 0,000<0,05 yang berarti bahwa faktor-faktor CashBack yang berpengaruh secara signifikan terhadap Minat Pembelian Produk di Burger KingCentral Park. Kesimpulan dari penelitian ini menyatakan bahwa berdasarkan hasil penelitian dari Koefisien Determinasi, dapat disimpulkan bahwa terdapat pengaruh dari Cash Back terhadap Minat Pembelian di Burger King Central Park sebesar 40,4\% sedangkan $59,6 \%$ dipengaruhi oleh variabel lain yang penulis tidak teliti.
\end{abstract}

Kata kunci: Cashback, Pembayaran Elektronik, Aplikasi Pembayaran

\begin{abstract}
In realizing this promotion, Burger King is collaborating with Go-Jek to implement a cash back promotion using the Go-Pay payment feature using the Go-Jek application. The reason for doing this research is because of the many changes in promotions that vary in various ways with different periods as well. The purpose of this study is to determine the effect of cash back using the Go-Pay payment feature using the Go-Jek application. This study is a causal associative study using a causal quantitative approach. The data collection technique used is by distributing questionnaires, and the results of the questionnaire data will be analyzed. Based on the distribution of $\mathrm{F}$ values, it is found that the calculated $\mathrm{F}$ is $69.881>\mathrm{F}$ table of 3.95 with a significance level of $0.000<0.05$ which means that the CashBack factors have a significant effect on Product Purchase Interest at Burger King Central Park. The conclusion of this study states that based on the results of research from the Coefficient of Determination, it can be concluded that there is an effect of Cash Back on Purchase Interest at Burger King Central Park by $40.4 \%$ while $59.6 \%$ is influenced by other variables that the authors are not careful about.
\end{abstract}

Keywords: Cashback, Electronic Payment, Payment Application 


\section{PENDAHULUAN}

Pada era modern seperti ini penggunaan teknologi jelas tak lekang oleh tiap sector yang ada di industry di Indonesia. Seperti layaknya pada sector makanan dan minuman yang ada juga tak lekang oleh teknologi. Terbukti dengan adanya banyak bermunculan beberapa aplikasi pemesanan dan bahkan ada fitur pembayaran pada pembelian makanan dan minuman.

Pada bukunya Kotler (2016) mengatakan pemasaran itu adalahproses sosial yang dimana seorang individu dan dalam kelompok akanmendapatkan apa yang mereka inginkan dan mereka butuhkan dengan menawarkan ataupun menciptakan sebuah nilai tukar produk secara bebas kepihak lainnya.

Grafik 1: Tren Data Pertumbuhan Industri Makanan dan Minuman, Q1 2010 Q4 2020 (Per Kuartal)

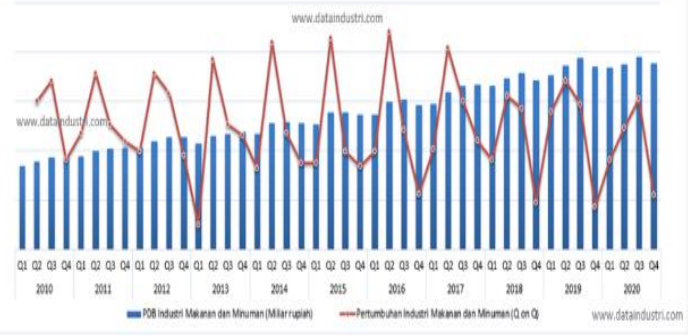

Dapat dilihat dari grafik diatas, bahwa di tahun 2018 hingga 2020 mengalami fluktuatif dan mengalami penurunan yang signifikan di kuartal 4 (Q4) akhir 2020 yang bisa saja ini terjadi karena era pandemic Covid-19. Menarik dilihat digrafik tersebut bahwa Produk Domestik Bruto (PBD) terus meningkat dan meningkat setiap tahunnya.

Dilansir pernyataan dari Handy Irawan (2015) dalam kutipannya menyatakan dimana konsumen Indonesia memiiki beberapa karakteristik-karakteristik yang cukup tergolongberbeda dengan yang lainnya didalam proses pembelian. Dengan salah satu-nya adalahsebuah pembelian yang implusive. Proses ini implusive ini merupakan pembelian yang di lakukan oleh konsumen tanpa perencanaan sebelumnya. Dalam membeli produk, konsumen biasanya tidak terpikir untuk membelibarang tersebut sebelumnya, namun dengna berbagai macam dorongan dan 'bujukan' secara srimulus, maka pembelian implusive ini sering kali terjadi oleh setiap individu pada umumnya. Sebagai contohnya saja adalah sebuah potongan yang diberikan kepada harga dapat memunculkan sebuah hasrat untuk dapat melakukan sebuah pembelian implusive yakni pembelian tanpa adanya tujuan dan rencana yang disusunsebelumnya.

Sumber: www.dataindustri.com

Table 1. Volume dan Nilai Transaksi Uang Elektronik 2020

\begin{tabular}{|l|l|l|l|l|l|l|l|l|l|l|}
\hline Periode & Januari & Februari & Maret & April & Mei & Juni & Juli & Agustus & September & Oktober \\
\hline $\begin{array}{l}\text { Volume } \\
\text { (Juta) }\end{array}$ & 457,94 & 431,46 & 401 & 324,87 & 298,18 & 339,89 & 381,57 & 386,7 & 366,78 & 392,88 \\
\hline $\begin{array}{l}\text { Nominal } \\
\text { (Rp. } \\
\text { Trilliun }\end{array}$ & 15,87 & 15,17 & 15,03 & 17,55 & 15,03 & 14,95 & 16,09 & 17,23 & 17,68 & 18,79 \\
\hline
\end{tabular}

Sumber Data: Bank Indonesia (2021)

Berdasarkan dari table diatas, secara akumulasi nilai transaksi elektronik sepanjang 2020 hingga Oktober mencapai Rp163,4 triliun. Nilai yang terakumulasi tersebut sudah melampaui dengan transaksi sepanjang 2019 yang mencapai Rp145,16 triliun. Namun secara akumulasi volume transaksi uang elektronik YtD per Oktober mencapai 3,78 miliar transaksi atau jauh lebih rendah ari 2019 yang sebanyak 5,23 miliar transaksi. 
Strategi promosi yang di lakukan oleh Burger King di Central Park (Sumber : http://bkdelivery.co.id/) :

Kupon Hemat Special Bulanan : Promosi bulanan yang menawarkan berbagai macam menu paket yang memberikan potongan $40 \%$ hingga 50\% dalam bentuk kupon kertas maupun kupon online melalui media sosial.

Cash Back Go-pay: Promosi yang bekerja sama dengan Go-Jek dengan mendapatkan potongan harga $30 \%$ pada hari tertentu dengan berbelanja dengan minimal tertentu.

Double Deal: Promosi dengan membeli 2 atau lebih produk tertentu yang sudah di tetapkan dengan harga yang sudah di tetapkan dan lebih murah dari harga normal per produk.

\section{Rabat (cashback)}

Definisi dari rabar adalah penawaran yang diberikan dari si pemberi tawaran untuk mengembalikan sejumlah nominal uang dalam jumlah tertentu kepada beberapa konsumen yang telah membeli sebuah produk atau jasa (Moriarity et al.,2011). Dengan dapat berupa kupon yang nantinya akan dapat dibelanjakan atau digunakan untuk transaksi berikutnya. Pengembalian uang tunai atau rabat ini lebih seperti voucher berharap bahwa penurunan atau pemotongan sebuah harga terjadi setelah pembelian itu terjadi daripada di outlet ritel. Pelangganakan mengirimkan "Bukti Transaksi Pembelian" kepada produsen, yang kemudian akan mengembalikan sejumlah uang dari harga pembelian melalui dari email.

Menurut Kotler dan Amstrong (2012), Pengembalian dana dan rabat merupakan promosi pengembalian dana (refund) atau rabat (rabate) ditawarkan oleh pemasar dalam bentuk mengembalikan sejumlah tertentu uang ketikan produk dibeli secara satuan atau dikombinasikan dengan produk lain. Pengembalian dana bertujuan untuk meningkatkan jumlah atau frekuensi pembelian dana ini secara temporer mendorong konsumen memenuhinya. Konsumen melihat pengembalian dana dan rabat sebagai hadiah atas suatu pembelian dana dan rabat sebagai hadiah atas suatu pembelian hal ini di ungkapkan oleh Agus Hermawan (2012) di kutip oleh Y Setiyowati (2016).

pengukuran dan pengembalian rabat dana biasanya akan menggunakan ketiga indikator sebagai berikut :

\section{Jumlah nominal dari pengembalian dana}

Cashback yang akandiberikan tentunya akan sesuai dengan kesepakatan nominal yang telah disepakati sebelumnya sesuai dengan kondisi dan persyaratan yang telah diberikan oleh perusahaan sebelumnya.

2. Kesesuaian dengan kesepakatan yang diberikan

Sebuah perusahaan biasanya akan memberikan sebuah kesepakatan yang dimana akan menguntungkan kedua belah pihak seperti yang ada dipoin ini tentang kespakatan dari kesesuaian yang telah diberikan.

\section{Ketepatan waktu dalam pengembalian dana}

Tentunya pada setiap pengembalian dana atau cashbackyang diberikan ini adalah termasuk dalam kecepatan dan ketepatan waktu dalam melakukan proses pengembalian dana dari perusahaan ke pada konsumen terkait. Dimana semakin sesuai dengan waktu dan kecepatan yang telah ditentukan maka tentu saja kepuasan dari konsumen yang menerima promosi tersebut

\section{METODOLOGI}

Subjek penelitian biasanya mempunyai peran yang strategis karena pada subjek penelitian ini, inilah data yang berhubungan tentang variabel yang penelitian yang akandiamati. Tempat penelitian ini yang dijadikan sebagai adalah Burger King Central Park. Sugiyono (2017) mengatakan bahwa objekpenelitian adalah "sasaran ilmiah untuk mendapatkan data dengan tujuan dan kegunaan tertentu tentang sesuatu hal objektif, valid dan reliabel tentang suatu hal (variabel tertentu)".

Jenis penelitian digunakan adalah menggunakan penelitian kuantitatif yaitu penelitian dengan 
menggunakan metode penggumpulan data menggunakan populasi dan sempel. Sehingga menjadi sistematis, terstruktur, tersusun, dan menggunakan analisis angka-angka statistic.

Menurut Arikunto (2013), populasi adalah keseluruhan dari subjek penelitian. Maka dengan kata lain populasi ini juga dapat dikatakan sebagai jumlah yang ada pada objek/subjek yang nantinya akan dipelajari, tetapi dengan melibatkan seluruh bentuk dan tipedari subjek yang sedang diteliti. Dalam penelitian ini, populasi yang akan diambil adalah jumlah pelanggan yang berkunjung ke Burger King Central Park.

Dalam penelitian ini, penulis menggunakan teknik nonprobability sampling dengan jenis sampling purposive dimana sampling purposive adalah teknik penentuan sampel dengan pertimbangan tertentu yang menurut Sugiyono (2017). Teknik penelitian ini dilakukan oleh penulis dikarenakan sampel yang dituju oleh penulis hanya responden yang pernah melakukan pembelian makanan dan minuman di Burger King Central Park menggunakan fitur pembayaran Go-Pay.

Menurut Hair et. aldalam Prawira (2010) menyatakan bahwa sampel yang digunakan sebagai responden bisa diambil 5 kali dari jumlah pertanyaan/pernyataan dari indikatoryang terdapat dalam kuesioner. Terdapat 1 variabel bebas yang memiliki 3 indikator dan 1 variabel terikat yang memiliki 4 dimensi, dan total pernyataan yang dibuat untuk penelitian ini berjumlah 21 pernyataan. Maka dari itu, jumlah minimal sampel dalam penelitian ini adalah $5 \mathrm{x}$ $21=105$ responden.

\section{HASIL DAN PEMBAHASAN}

Pada bagian ini, penulis menguraikan penjelasan mengenai hasil dari penyebaran kuesioner yang sudah di olah oleh penulis untuk mengetahui pengaruh cashback menggunakan fitur pembayaran Go-Pay melalui aplikasi GoJek terhadap minat pembelian produk di Burger King Central Park, khususnya pada kalangan dewasa range umur dari 18 tahun ke atas, menurut Undang-undang no. 23 tahun 2002 tentang Perlindungan Anak pasal 1 ayat (1), "Anak adalah seseorang yang belum berusia 18 (delapan belas) tahun, termasuk anak yang masih dalam kandungan." Artinya batas usia dewasa menurut aturan ini adalah 18 tahun ke atas. Subjek penelitian ini adalah kelompok dewasa dengan range usia 18 tahun keatas yang sudah pernah membeli produk makanan dan minuman Burger King Central Park menggunakan fitur pembayaran Go-Pay. Penulis menyebarkan kuesioner kepada 105 responden selama kurang dari 1bulan diperiode Februari ke Maret 2021.

Data yang ditanyakan kepada responden adalah, pernah atau tidak pernah mengunjungi Burger King Central Park, pernah atau tidak pernah membeli produk Burger King Central Park, pernah atau tidak pernah bertransaksi menggunakan Go-Pay di Burger King Central Park, Nama, Usia, Jenis kelamin, Domisili, Pendidikan terakhir, Pekerjaan, Pengeluaran perbulan.

Tabel 2. Hasil Uji Deskriptif

\begin{tabular}{|c|c|c|c|c|}
\hline \multicolumn{2}{|c|}{ ITEM } & $\begin{array}{c}\text { Mean } \\
\text { PerIndika } \\
\text { tor }\end{array}$ & $\begin{array}{c}\text { StandarDev } \\
\text { iasi }\end{array}$ & $\begin{array}{c}\text { Mean } \\
\text { Pervaria } \\
\text { bel }\end{array}$ \\
\hline \multirow{3}{*}{$\begin{array}{l}\text { Besarnya } \\
\text { Jumlah } \\
\text { Pengembal } \\
\text { ian Dana }\end{array}$} & $\begin{array}{c}\text { Besarnya } \\
\text { Jumlah1 }\end{array}$ & 3,64 & 0,502 & \multirow[t]{3}{*}{3,54} \\
\hline & $\begin{array}{c}\text { Besarnya } \\
\text { Jumlah2 }\end{array}$ & 3,41 & 0,549 & \\
\hline & $\begin{array}{c}\text { Besarnya } \\
\text { Jumlah3 }\end{array}$ & 3,58 & 0,533 & \\
\hline \multirow{2}{*}{\begin{tabular}{|l|} 
Kesesuaian \\
Dengan \\
Janji
\end{tabular}} & $\begin{array}{c}\text { Kesesuaia } \\
\mathrm{n} 1\end{array}$ & 3,46 & 0,555 & \multirow[t]{2}{*}{3,52} \\
\hline & $\begin{array}{c}\text { Kesesuaia } \\
\text { n2 }\end{array}$ & 3,57 & 0,516 & \\
\hline \multirow{2}{*}{$\begin{array}{l}\text { Kecepatan } \\
\text { Pengembal } \\
\text { ian Dana }\end{array}$} & $\begin{array}{c}\text { Kecepata } \\
\text { n } 1 \\
\end{array}$ & 3,61 & 0,509 & \multirow{2}{*}{3,6} \\
\hline & $\begin{array}{c}\text { Kecepata } \\
\text { n } 2\end{array}$ & 3,55 & 0,537 & \\
\hline
\end{tabular}

Sumber: Hasil Olahan data oleh Penulis (2021)

Berdasarkan tabel diatas, dapat dijelaskan bahwa nilai mean pada indikator Besarnya Jumlah Pengembalian Dana adalah 3,54. Untuk indikator Besarnya Jumlah 1 yaitu 3,64 sebagai nilai mean tertinggi, sedangkan nilai mean terendah adalah 3,41 
untuk Besarnya Jumlah 2. Dari ketiga indikator tersebut didapatkan bahwa indikator tertinggi ada pada indikator Besarnya Jumlah 1 yang diwakili dengan pernyataan "Saya melakukan transaksi menggunakan fitur aplikasi pembayaran GoPay di Burger King Central Park karena ingin mendapatkan pengembalian dana" Dengan standar deviasi sebesar 0.502 . Sementara untuk nilai mean terendah terdapat pada indikator Besarnya Jumlah 2 yang diwakili dengan pernyataan "Saya merasa Burger King Central Park menawarkan pengembalian dana menggunakan fitur pembayaran Go- Pay dalam jumlah besar" dengan standar deviasi sebesar 0.549 .

Pada indikator Kesesuaian dengan Janji, dapat dijelaskan bahwa nilai mean tertinggi terdapat pada indikator Kesuaian 2 sebesar 3,57 yang diwakili dengan pernyataan "Saya mendapatkan jumlah pengembalian dana saat melakukan transaksi menggunakan fitur pembayaran Go-Pay di Burger King Central Park

\section{KESIMPULAN}

Berdasarkan hasil analisis data dan hasil olahan data dapat disimpulkan bahwa masing-masing dari indikator yang ada dicashback, Kecepatan Pengembalian Dana menjadi indicator yang paling pertama atau dominan, lalu Besarnya Jumlah Pengembalian Dana sebagai urutan kedua sebagai indicator dari cashback, dan yang diurutan terakhir adalah Kesesuaian Janji.

\section{DAFTAR PUSTAKA}

Arikunto, S. (2013). Prosedur Penelitian: Suatu Pendekatan Praktik. Jakarta: Rineka Cipta.

Armstrong, Gary dan Kotler, Philip. (2012). Prinsip-prinsip Pemasaran. Edisi 13 . Erlangga. Jakarta

Efendi. F, 2019, Pengaruh Cashback Menggunakan Fitur Pembayaran Go-
Pay Melalui Aplikasi Go-Jek

Terhadap Minat Pembelian Produk Di Burger King Central Park, Skripsi Sarjana Hospitality dan Pariwisata, Universitas Bunda Mulia

https://www.bareksa.com/berita/pasarmodal/2020-12-17/bi-tren-dgitalisasiberlanjut-transaksi-uang-elektroniknovember-melesat-2027-persen

https://www.dataindustri.com/produk/datapertumbuhan-industri-makanan-dan$\underline{\text { minuman/ }}$

Kotler, Philip and Kevin Lane Keller, (2016), Marketing Management, Edisi 16, New Jersey: Prentice Hall Published

Moriarty, Sandra, dkk. 2011 .Advertising. Jakarta, Kencana Prenada Media Group.

Setiyowati, Yenita. (2016). Pengaruh Alat Promosi Penjualan Dan Persepsi Kualitas Terhadap Keputusan Pembelian Hp Merek Samsung Di Surabaya.

(https://id.123dok.com/document/yjo 3rwkz-pengaruh-alat-promosipenjualan-dan-persepsi-kualitasterhadap-keputusan-pembelian-hpmerek-samsung-di-surabayaperbanas-institutional-repository$\underline{\text { 2.html) }}$

Sugiyono. (2017). Metodologi Penelitian Kuantitatif, Kualitatif, dan R\&D. Bandung: Alfabeta.

Undang-undang no. 23 tahun 2002 tentang Perlindungan Anak pasal 1 ayat (1). Lembaran Negara Republik Indonesia Tahun 2002 Nomor 4301. Jakarta. 